\title{
CORRECTION
}

\section{Correction to: Building the Prestige of Archivum Immunologiae et Therapiae Experimentalis: From a Little Known to an Internationally Recognized Journal}

\author{
Hubert Krotkiewski ${ }^{1}$. Andrzej Górski ${ }^{1} \cdot$ Michał Zimecki $^{1}$
}

Published online: 7 December 2018

(c) L. Hirszfeld Institute of Immunology and Experimental Therapy, Wroclaw, Poland 2018

\section{Correction to: \\ Archivum Immunologiae et Therapiae Experimentalis \\ (2018) 66:407-413 \\ https://doi.org/10.1007/s00005-018-0529-3}

"According to JCR data, updated in October 2018 by Clarivate Analytics, the corrected IF value of Archivum Immunologiae et Therapiae Experimentalis for the year 2017 is 2.991".

The original article can be found online at https://doi.org/10.1007/ s00005-018-0529-3.

Hubert Krotkiewski

krotkiew@iitd.pan.wroc.pl

$1 \quad$ Hirszfeld Institute of Immunology and Experimental

Therapy, Polish Academy of Sciences, Weigla 12,

53-114 Wrocław, Poland 